DOI: 10.2478/linpo-2013-0006

\title{
FREQUENCY ANALYSIS OF SINGULAR FIRST-PERSON PRONOUNS AND VERBS IN THE UTTERANCES OF SCHIZOPHRENIA PATIENTS AND HEALTHY CONTROLS. A RESEARCH REPORT
}

\author{
MONIKA OBRĘBSKA
}

\begin{abstract}
Monika Obrębska. Frequency Analysis of Singular First-person Pronouns and Verbs in the Utterances of Schizophrenia Patients and Healthy Controls. A Research Report. Lingua Posnaniensis, vol. LV (1)/2013. The Poznań Society for the Advancement of the Arts and Sciences. PL ISSN 00794740, ISBN 978-83-7654-273-7, pp. 87-98.
\end{abstract}

Purpose: The purpose of this article is to present the results of a frequency analysis of first-person pronouns and verbs in utterance texts of schizophrenia patients and healthy controls.

Method: The study involved 130 hospitalized psychiatric patients diagnosed with paranoid schizophrenia and 130 healthy individuals. As a result of the study, the largest corpus to date of marked utterance texts of schizophrenic patients in the Polish language was obtained. The ratio of the number of singular first-person personal pronouns and verbs to the total number of personal pronouns and verbs used in any particular text was calculated and was then averaged for each of the four studied groups: a group of patients with positive schizophrenia symptoms, a group of patients with negative schizophrenia symptoms, a control group for the patients with positive symptoms, and a control group for the patients with negative symptoms.

Results: The highest mean was found for the group of patients with positive schizophrenia symptoms, and the lowest for the group of healthy individuals. This difference was found to be statistically significant.

Conclusion: The "egocentric orientation" and difficulty in defining one's own identity experienced by psychotic patients, especially those with the positive type of schizophrenia, are reflected in their lexical choices.

Monika Obrębska, Institute of Psychology, Adam Mickiewicz University, Poznań, Monika.Obrebska@ amu.edu.pl

\section{INTRODUCTION}

The purpose of this article is to present the results of a frequency analysis of first-person pronouns and verbs in utterance texts of healthy individuals and individuals suffering from paranoid schizophrenia, assuming that the morbid process and the dominant clinical symptoms will significantly modify the subjects' lexical choices. We assume that the "egocentric orientation" and difficulty in defining one's own identity experienced by psychotic patients, especially those with positive type schizophrenia, will be reflected in their lexical choices, 
that is, in a more frequent use of first-person pronouns and verbs, as compared with healthy individuals.

The present study is a part of a larger project, the preliminary results of which have been presented in several other publications (OBRĘBSKA 2011: 29-45; OBRĘBSKA \& NowAK 2011: 49-62; OBRĘBSKA \& OBRĘBSKI 2011: 161-170).

The attempt to link the formal and content-related features of language with the psychological processes of its users has been a subject of interest for psychologists of many theoretical orientations, especially those representing the narrative approach in psychology (Trzebiński 2002; Pennebaker et al. 2003; Janusz et al. 2008; Straś-RomanowsKa et al. 2010; DRYLL \& CIERPKA 2011). This approach sees narration as a special form of cognitive representation of reality, where the level of utterance is just an external manifestation of a complex richness of the individual's inner world, "a verbal representation of a changing reality" (BoKUs 2005: 246).

In psycholinguistic research, as pointed out by Jacek Paluchowski (PALUCHOWSKI 2010: 53-82), the content (meaning) is a result of inference and interpretation of the text, and it informs us about a way of seeing the world, the non-language characteristics of the sender of the message, the reasons (intentions) for formulating the message and the effect that a given message exerts on its receivers. The goal of content analysis is therefore to "enter into the inner world of meanings" of the narrator of the story, to read "the structure of inner experience" hidden beneath a "structured sequence of stimuli", that is, the language material (PAluchowski 2010: 59, 58, 54).

Frequency analysis of first-person pronouns and their psychological interpretation was conducted by Jastrzębska and Dryll (JASTRZĘBSKA \& DRYLL 2008: 133-153), who linked their use with several aspects of the model of the self - the "sense of self", the need to be differentiated from others (by emphasizing the "I"), as well as the need to be similar and close to others, even to be a part of others (by emphasizing the "we"). The large number of first-person singular pronouns in subjects' utterance texts was interpreted as reflecting a need to manifest and define the self through differentiation from others. Jastrzębska and Dryll emphasize that this need is related to, on the one hand, the sense of one's own uniqueness, and on the other hand, to the lack of a "sense of self" and a difficulty in defining one's own identity. A "high-pronoun" person stresses their own personhood in the texts, and becomes their own reference point, thus concealing their lack of self-knowledge and inability to express themselves in another way.

Patients with schizophrenia often display unusual language impairments (CovingTON et al. 2005: 85-98; KUPERBERG 2010: 576-589). Some interesting results concerning personal pronoun usage in the context of schizophrenia were reported by Andrew R. Watson and others (WATSON et al. 2012: 342-343). Their research was conducted on a group of people at high genetic risk of schizophrenia and aimed to analyze the use of various lexical categories (singular and plural nouns, personal pronouns, verb tenses, etc.). The only significant difference was found in the frequency of second-person pronoun usage between two subgroups of the research group: people who developed schizophrenia symptoms later on (18 months apart) and those who did not. The authors interpret this result as "support for the view that people who go on to develop schizophrenia may have an abnormality in the deictic frame of interpersonal communication" (p. 342).

In the present study we decided to examine the frequency of use of singular first-person personal pronouns in utterance texts of healthy individuals and individuals suffering from 
paranoid schizophrenia. A similar analysis was carried out for the plural, but the differences between the groups were not found to be statistically significant $(\mathrm{F}(3.256)=1.471 ; \mathrm{p}>0.05)$.

In order to organize the clinical symptoms of the illness, we followed Andreasen and Crow's (ANDREASEN \& CROW 1979: 1315-1321) division into positive and negative types of schizophrenia. This division is based on the assumption that in schizophrenia we can distinguish symptoms which constitute a new quality, being in a way an addition to the expressions of human psychological functioning, from symptoms which result from a decline in certain psychological functions. For this reason the positive symptoms are often called generative symptoms, while the negative ones are known as deficit symptoms.

We can speak of positive (generative) clinical level symptoms when apparent emotional tension, motor arousal, delusional interpretations of events or hallucinations, cognitive disturbances, grandiosity, suspiciousness or hostility is manifested. These emerge most often in the acute phase of schizophrenia and disappear under the influence of standard neuroleptics. We speak of negative (deficit) symptoms when diminishment or absence of characteristics of normal function such as emotional expressiveness, communicative ability or reactivity to external events is observed. Symptoms of this type are also characterized by shallow affect, indicated by impoverished mimic expression, inadequacy of emotion, lack of manifestations of will, decline in spontaneous movements, and apathy. In the context of mental functioning we emphasize the presence of various cognitive deficits (impoverished content), observed in the form of complete lack of speech (mutism) or its severe inhibition (impoverished speech). The appearance of negative symptoms indicates the persistence of the illness in its course and its resistance to pharmacological treatment.

This differentiation of positive and negative syndromes in the clinical presentation has led to the development of a classification based on the criterion of predominance of one of them. Based on this distinction two types of schizophrenia are distinguished: the positive type, dominated by generative symptoms, and the negative type, dominated by deficit symptoms.

This two-dimensional, positive-negative clinical model has been repeatedly tested with the use of specially constructed tools, especially the PANSS scale (Positive and Negative Syndrome Scale for Schizophrenia), which is also used in current work as a tool for description of positive and negative symptoms of schizophrenia (KAY et al. 1987).

A sudden onset of psychosis may, from a psychological point of view, be seen as a manifestation of a "severe, identity-related individuation crisis" (DRAT-RUSZCZAK 1995: 202). This assumption is supported by longitudinal studies of the dynamics of personality change in individuals diagnosed with schizophrenia, conducted by Stanisława Steuden (STEUDEN 1997). A disordered sense of identity was present in the majority of studied patients and their concept of self was found to be vague and poorly structured. A reflection of a disordered identity is the sense of alienation from self and others, withdrawal from social contact, inability to engage in and complete tasks, passive and dependent attitude, sense of alienation from and lack of agency of one's own actions.

Patients with schizophrenia often have difficulties with social and emotional cognitive processing, including self-reflective processes: "This self-reflective processing is essential in the evaluation of one's personal behavior as well as in interpersonal communication. More specifically, it has been proposed that self-reflective processing may underlie poor 
illness insight in patients with schizophrenia." (LIEMBURG et al. 2012: 1). The results of Liemburg's research show that patients with poor insight (unawareness of illness) had significantly more positive symptoms and displayed a lower connectivity within the anterior cingulate and precuneus compared with patients with good insight.

The disordered identity in schizophrenia and lack of insight are accompanied by a positive evaluation of the self and of the social situation, which perpetuates the disordered individuation. Amplified self-esteem can also be a result of the operation of a defense mechanism called "positive defensiveness" (STEUDEN 1997: 60), the function of which is to strengthen the self and provide a defense against the experiences of anxiety, rejection and lack of personal satisfaction. The positive evaluation justifies the concentration on oneself and the withdrawal from engagement in social relationships, leading to a stronger experiencing of self than of the external world. Antoni Kępiński (KęPIŃSKI 2001) even writes about "the swelling of the self" in schizophrenia, quoting Freud's description of schizophrenia as a "narcissistic neurosis", and Beck and others (BECK et al. 2010) speak of an "egocentric orientation", characteristic of delusional thinking and of the delusions of reference with regard to irrelevant events. They note that this biased relating of events to oneself betrays a hidden assumption of the patient that he is in the centre of attention of the whole world: "Depending on the content of the egocentric orientation, the patients falsely perceive themselves as a main subject of interest of others (people or supernatural beings), of their malice, of their intrusive or benevolent actions. They may simultaneously perceive themselves as helpless and as stronger than others, as weak and as omnipotent. They also attribute personal meaning to events which do not have a personal character or do not concern them, and they look for the proof of the intentional action of the external forces in random occurrences and coincidences" (BECK et al. 2010: 57).

Assuming, after Jastrzębska and Dryll, that a high number of singular first-person pronouns in utterance texts of the subjects may be, on the one hand, a sign of the sense of one's own uniqueness, and - on the other hand - of a lack of the "sense of self" and difficulty in defining self identity, we can expect that their number will be higher in the utterances of schizophrenic patients, especially those with predominantly positive symptoms related to positive evaluation and egocentric orientation, compared with healthy individuals.

\section{METHOD}

In order to verify the above hypothesis, we conducted a study involving 132 hospitalized psychiatric patients diagnosed with paranoid schizophrenia. The study was financed through the individual research project no. N N106 039734 of the Ministry of Science and Higher Education. The study was carried out in the years 2008-2009 at five large neurological and psychiatric care centers in Poland:

1. the Regional Hospital for Mental Health and Psychiatric Patients in Gniezno;

2. the Regional Hospital for Mental Health and Psychiatric Patients in Cibórz;

3. the Regional Neuropsychiatric Hospital in Kościan;

4. the Józef Babiński Hospital for Neurological and Psychiatric Patients in Kraków;

5. the Independent Public Hospital for Neurological and Psychiatric Patients in Międzyrzecz. 
Both in the pilot study and in the later study proper, all subjects gave their written consent to participate in the research and to have their utterances recorded on a dictaphone. To take part in the study, patients were required to be able to maintain relatively good contact with their social environment. In accordance with the principles of purposive sampling, patients were referred for the study on the basis of a specialist medical diagnosis (recognized paranoid schizophrenia) by the treating psychiatrist, who, having sound knowledge of both the state of the patient and the framework of the study, decided whether a given patient would be able to participate.

The patients' examination was conducted with the use of a set of pictures. These were selected by five experts with experience in working with psychotic patients (3 psychiatrists and 2 practicing psychologists), and approved by the Ethics Committee of the UAM Institute of Psychology. The selection was made from 14 black-and-white and realistic photographs taken from a collection of works of world-famous artistic photographers: W. Ronis, R. Doisneau, Z. Matuszewski, Z. Nasierowska, K. Kurzydło. The photographs depicted landscapes (4), portraits (3), animals (3) and interpersonal situations involving multiple persons (4). The experts were asked to rank the photographs according to two criteria: patient's wellness (low risk of patient's deterioration), and content richness (better narrative stimulation). Five photographs with the highest total ranks were chosen. These were:

1. "Chez Maxe" by Willy Ronis - people dancing outdoors;

2. "Villa Médicis" by Willy Ronis - a man playing with a child in a park;

3. "Sélestat" by Willy Ronis - a family sitting at a table;

4. "Pluie d'été" by Robert Doisneau - children playing in the rain;

5. "Złodziejaszki” by Zbigniew Matuszewski - cats drinking milk from a bucket.

Subjects were shown a sequence of five photographs, always in the same order, and were asked to describe what they saw on them. The examination ended when the subject signaled that he or she had finished, by saying e.g. "that's it", "that's all."

All utterances were recorded on a dictaphone, which enabled subsequent replaying of the free flow of speech. We deemed it important that the utterances should be non-directed and spontaneous in character. Many researchers (ŻURKo 2008: 109) emphasize the higher psychological value of spontaneous utterance texts over written texts, as the former allow one to enter into a personal system of meanings and promote the generation of a deepened story by transgressing the cultural and formal norms of organization of text.

After this part of the study was finished, the researcher, together with the patient's treating psychiatrist, filled in the PANSS scale in order to assign the patient to the group with positive or negative type schizophrenia. In the course of the research we identified a total of 80 patients with positive and 52 patients with negative symptoms of schizophrenia (two recordings from the latter group turned out to be incomprehensible, therefore 50 recordings of utterances of patients with negative symptoms were used in the analysis).

After testing the experimental group, a similar procedure (showing photographs) was used to test healthy individuals from the control group. A control group $(n=130)$ matched to the patients in terms of age, sex and education level was used; the main differentiating variable between the two groups was morbidity. This method of sampling allowed the control of demographic variables - sex, age and education - which could also have influenced lexical choices and the organization of utterances by subjects. On this basis two reference control 
groups were distinguished: a control group for the patients with positive symptoms (cp) and a control group for the patients with negative symptoms of schizophrenia (cn), identical to the corresponding experimental groups with regard to demographic variables. For subject characteristics, see Table 1.

Table 1. Demographical data

\begin{tabular}{|l|c|c|c|c|c|c|c|c|c|c|c|}
\hline \multirow{2}{*}{ Groups } & \multicolumn{2}{|c|}{ Sex } & \multicolumn{5}{c|}{ Age } & \multicolumn{3}{c|}{ Education } & \multirow{2}{*}{ Total } \\
\cline { 2 - 11 } & W & M & $18-30$ & $31-40$ & $41-50$ & $51-60$ & $61-70$ & Primary & Secondary & Higher & \\
\hline $\begin{array}{l}\text { Patients with } \\
\text { positive } \\
\text { schizophrenia } \\
\text { symptoms }\end{array}$ & 37 & 43 & 27 & 13 & 19 & 16 & 5 & 31 & 38 & 11 & $\mathrm{~S}=80$ \\
\hline $\begin{array}{l}\text { Patients with } \\
\text { negative } \\
\text { schizophrenia } \\
\text { symptoms }\end{array}$ & 17 & 33 & 11 & 13 & 14 & 9 & 3 & 32 & 16 & 2 & $\mathrm{~S}=50$ \\
\hline
\end{tabular}

In the group of patients with positive schizophrenia symptoms there was a slight predominance of men (54\%), of young individuals, within the $18-30$ age range (34\%), and of individuals with secondary education (47.5\%). In the group of patients with negative schizophrenia symptoms (as well as the control group for the negative patients) we found a predominance of men (66\%), of middle-aged individuals, within the $41-50$ age range $(28 \%)$, and individuals with primary education (64\%). This distribution agrees with the assumption of McGlashan \& Fenton (1992) and other clinicians, who associate the level of intensity of positive and negative results primarily with the phase of the illness. In its initial phase one usually observes a predominance of positive symptoms, which, with the progression of the illness, develop into negative symptoms. In the present study most of the patients with positive symptoms were hospitalized for the first time, they had not yet experienced significant disruption to their daily lives and had no cognitive deficits; hence their younger age and higher education level in comparison with the group of patients with negative symptoms.

After the completion of the testing all utterance texts were transcribed using Transcriber software. The UAM Text Tools software package, created at the UAM Department of Mathematics and Computer Science, was used for text annotation. Each word of the text was marked with morphological information, including the part of speech and morphological attributes (such as grammatical number, gender, person, etc.), using data from the Polex/ PMDB electronic morphological dictionary (VETULANI et al. 1988). The automatically generated annotation clearly required manual verification, which was performed by two experts with a linguistic background (both with Ph.D. qualifications: one in general linguistics, the other in computer science in the domain of computational linguistics) and was based on the Contemporary Dictionary of the Polish Language by Bogusław Dunaj (DunAJ 2007) and the Dictionary of the Polish Language by Mieczysław Szymczak (SzYMCzAK 1982).

As a result of the study, the largest corpus to date of marked utterance texts of schizophrenic patients in Polish was obtained. The corpus contains 200000 words in total, threequarters of which represent utterances of schizophrenic patients. Patients with positive symptoms of schizophrenia generated significantly longer utterances (1500 words on aver- 
age) compared with patients with negative symptoms (300 words) and healthy individuals (300 words). The present study of the language of schizophrenic patients is the largest of all such studies conducted in Poland to date.

\section{RESULTS}

We calculated, separately for each subject, the ratio of singular first-person personal pronouns and verbs to all personal pronouns and verbs used in the text. This result was then averaged for each of the studied groups: experimental positive ( $p$ ) and experimental negative (n), control for patients with positive symptoms (cp) and control for patients with negative symptoms of schizophrenia (cn).

The means and standard deviations obtained for each group are given in Table 2.

Table 2. Means and standard deviations

\begin{tabular}{|c|c|c|}
\cline { 2 - 3 } \multicolumn{1}{c|}{} & Mean & Standard deviation \\
\hline $\mathrm{p}$ & 0.347 & 0.118 \\
\hline $\mathrm{n}$ & 0.289 & 0.157 \\
\hline $\mathrm{cp}$ & 0.234 & 0.126 \\
\hline $\mathrm{cn}$ & 0.235 & 0.125 \\
\hline
\end{tabular}

The mean values obtained for each group are illustrated in Figure 1.

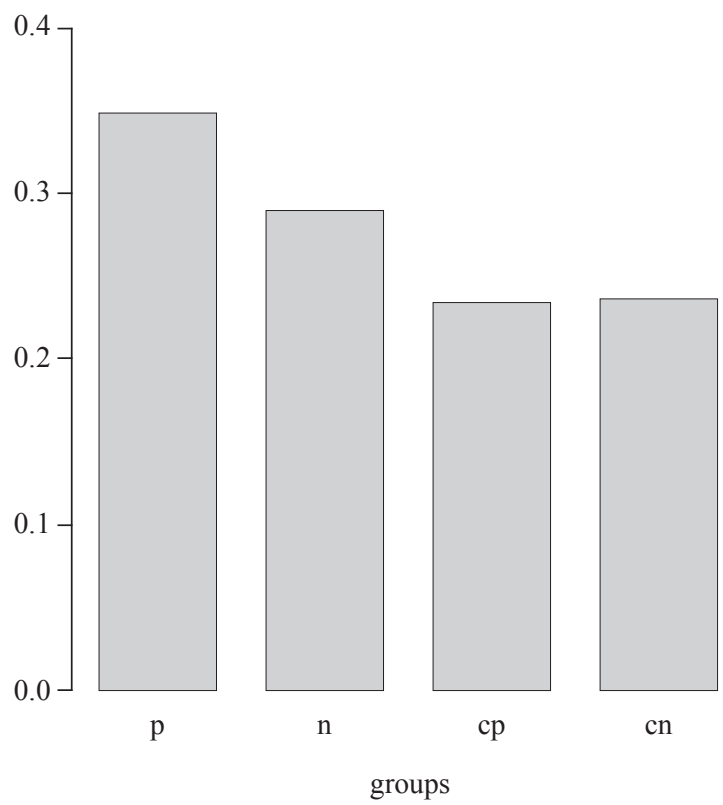

Fig. 1. Mean values for the frequency of use of first-person pronouns and verbs

The highest mean frequency of use of first-person pronouns and verbs was found for the group of patients with positive schizophrenia symptoms, and the lowest for the control 
group. This result supports the proposed research hypothesis and suggests a more frequent use of first-person personal pronouns and verbs by patients with positive schizophrenia symptoms, compared with patients with negative symptoms and healthy individuals. The high value of this mean suggests, in accordance with our theoretical assumptions, the accentuation of the self, resulting from egocentric orientation and alterations in perception of self.

In order to test the significance of the differences between the means, we performed an analysis of variance for independent samples. The F-test results for $p<0.05$ were found to be statistically significant: $F(3.256)=12.471 ; p<0.001$. To determine which pairs of averages differed significantly, a post hoc test was carried out, using Tukey's HSD comparison. The results are given in Table 3, with statistically significant results marked in bold font.

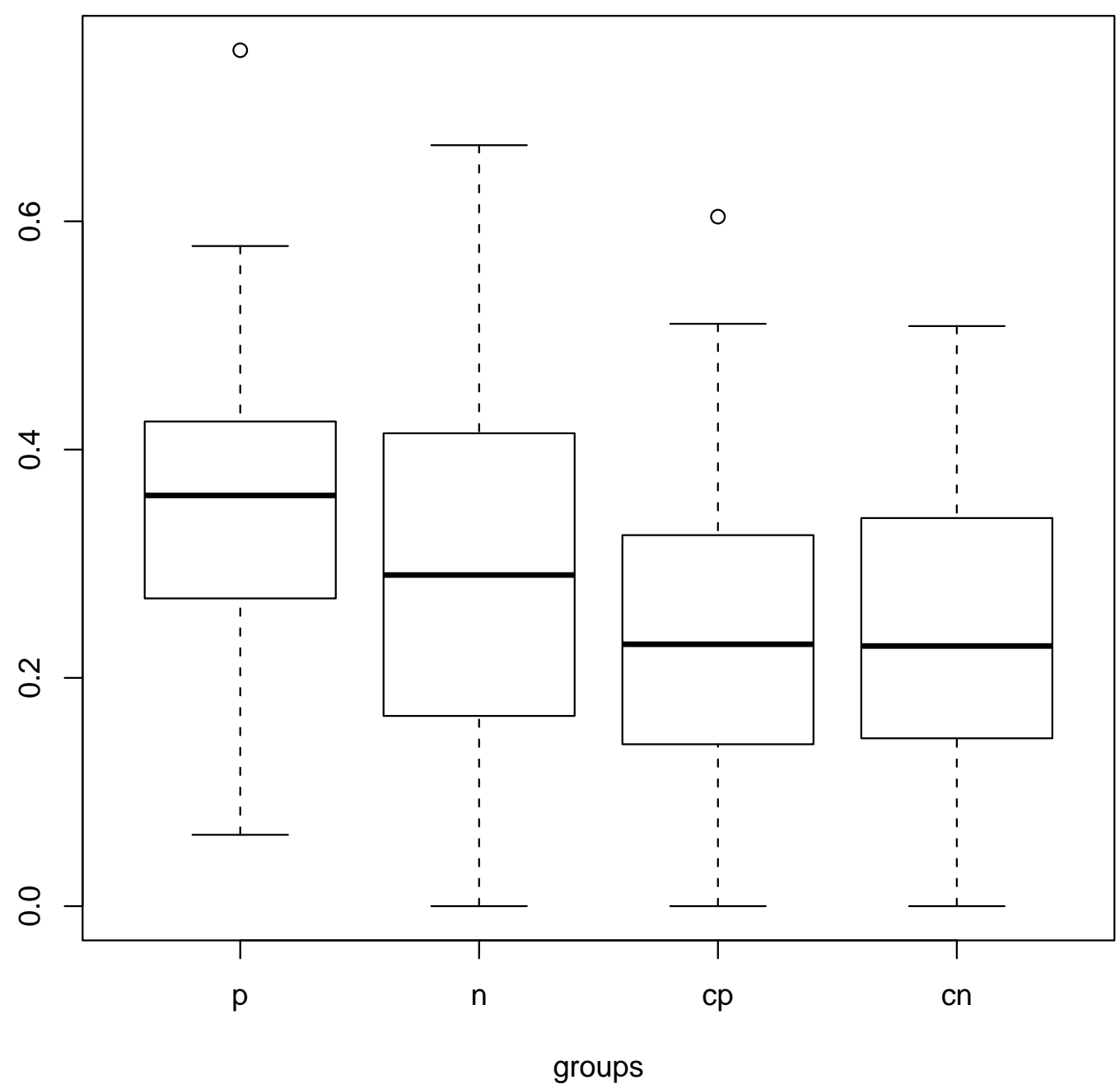

Fig. 2. Data distribution characteristics within each group 
Ta b le 3. Statistical significance results for the frequency of use of first-person pronouns and verbs

\begin{tabular}{|l|c|c|c|c|}
\hline Groups & Difference & $\begin{array}{c}\text { Lower limit of the } \\
\text { confidence interval }\end{array}$ & $\begin{array}{c}\text { Upper limit of the } \\
\text { confidence interval }\end{array}$ & Statistical significance \\
\hline cp-cn & -0.001 & -0.062 & 0.059 & 0.999 \\
\hline n-cn & 0.053 & -0.014 & 0.121 & 0.171 \\
\hline $\mathbf{p}$-cn & $\mathbf{0 . 1 1 2}$ & $\mathbf{0 . 0 5 1}$ & $\mathbf{0 . 1 7 3}$ & $\mathbf{p}<\mathbf{0 . 0 0 1}$ \\
\hline n-cp & 0.054 & -0.006 & 0.115 & 0.097 \\
\hline $\mathbf{p}$-cp & $\mathbf{0 . 1 1 3}$ & $\mathbf{0 . 0 5 9}$ & $\mathbf{0 . 1 6 6}$ & $\mathbf{p}<\mathbf{0 . 0 0 1}$ \\
\hline p-n & 0.059 & -0.002 & 0.119 & 0.062 \\
\hline
\end{tabular}

The differences between the group of patients with positive symptoms and the control groups - positive and negative - were found to be statistically significant. The statistical significance level of $p=0.06$ for the difference between the group of patients with positive symptoms and the group of patients with negative symptoms of schizophrenia was on the boundary of statistical significance and suggested a tendency for members of the two groups to use first-person pronouns and verbs in distinct ways. These results suggest that patients with positive symptoms of schizophrenia differ from the other groups in their more frequent use of singular first-person personal pronouns and verbs.

To illustrate the distribution of results within each group we prepared a box plot (Fig. 2).

The box plot shows a distribution of results similar to a normal distribution, as the values of mean and median are similar. Single cases of outliers were found in the positive patient group and the positive control group. The group of patients with positive symptoms was found to be the most homogeneous of all groups, as it showed the lowest dispersion of data, while the group of patients with negative schizophrenia symptoms was found to be the least homogeneous group, as illustrated by the length of the whiskers on the box plot and the value of the standard deviation.

\section{DISCUSSION}

The results of the present study have confirmed the hypothesis of the existence of differences in the frequency of use of singular first-person pronouns and verbs between a group of patients suffering from schizophrenia and healthy subjects. The highest number of firstperson pronouns and verbs was found in the utterance texts of patients with positive schizophrenia symptoms, while the lowest number was found in the group of healthy individuals. This difference was found to be statistically significant. According to our theoretical assumptions, this is the result of the morbid process, especially the "egocentric attitude" and alterations in perception of self, which are reflected in subjects' lexical choices.

On the other hand, the result pattern for patients with negative schizophrenia symptoms is not entirely clear. This group is the least homogenous, with the highest dispersion of results, which lie between the mean results of patients with positive symptoms and those of healthy individuals. It can be assumed that the group diagnosed as "patients with negative symptoms of schizophrenia" may include individuals who, after many years of treatment, may be regarded as healthy, or at least in the remission phase of the illness, as well as individuals who do not externally exhibit disturbing generative symptoms, such 
as delusions or hallucinations. BECK et al. (2010: 222) have called this phenomenon "the secondary negative symptoms, brought about by the occurrence of acute positive symptoms," and consider it a form of defense against a perceived personal or social threat: "social interactions can often be a triggering factor for voices, which causes many patients to withdraw and isolate themselves in order to reduce anxiety and embarrassment associated with such situations."

Taking these diagnostic difficulties into consideration, we have decided to examine this group of patients more closely, taking into account the year of onset of the illness. Let us reiterate that, according to the previously cited study by MCGLASHAN \& FENTON (1992), the level of intensity of positive and negative symptoms depends mostly on the phase of the illness. In its initial stage one can usually observe a predominance of positive symptoms at that point they are unstable and susceptible to treatment. In the subchronic phase, which develops after several years of illness, the intensity of negative symptoms increases, and they are manifested alongside positive symptoms. The chronic phase of the illness, however, is dominated by negative symptoms, which are most probably accompanied by structural changes in the brain.

Taking into account the year of illness onset for each individual, we divided the group of patients with negative symptoms of schizophrenia into two equinumerous subgroups (each of 25 persons). The first group consisted of individuals for whom the onset of schizophrenia had taken place not more than 4 years before the date of the study: for 12 subjects the onset had occurred in the year of the study, for 4 subjects it was one year earlier, for 5 subjects it was two years earlier, for one person it was three years earlier, and for 3 subjects it was four years earlier. The other group consisted of individuals with a longer history of illness, most often of more than ten years, sometimes even of several decades; values ranged from 8 to 59 years of illness.

In accordance with MCGLASHAN \& FENTON's (1992) results, we assumed that in the first group, including individuals in the initial and subchronic phase of the illness, we would more often observe what Beck, Rector, Stolar and Grant described as the masking of positive symptoms by secondary negative symptoms. Therefore, the results for this group of patients should be comparable with the results for patients with positive symptoms of schizophrenia, since this group may include incorrectly diagnosed patients with positive symptoms, for whom the negative symptoms are a pathological attempt to adjust to the situation of illness.

The other group consisted of already chronic patients, with a long history of illness, predominant deficit symptoms and associated structural changes in the brain. Optimistically speaking, this group - having undergone prolonged treatment - may include individuals whose long-term therapy had proved successful, and whose results would be similar to those of the healthy individuals.

The values of the means confirm the direction of the proposed relationship: results for the negative patients from the group with short history of illness $(\bar{x}=0.291)$ were comparable with the results for patients with positive symptoms of schizophrenia, whereas the results for the negative patients with long history of illness $(\bar{x}=0.286)$ were found to be similar to the results for the healthy individuals. Therefore, we can assume that the $\mathrm{n} 1$ group included individuals with secondary negative symptoms, which concealed the presence of 
acute positive symptoms, while the $\mathrm{n} 2$ group might have included individuals whose lexical choices resembled the choices of the healthy individuals.

Despite the fact that this difference was not found to be statistically significant, it implies some interesting relationships, requiring further research, involving a larger and more homogeneous sample.

\section{REFERENCES}

Andreasen Nancy, Crow Tim. 1979. "Thought, Language and Communication Disorders. Clinical Assessment, Definition of Terms and Evaluation of Their Reliability." Archives of General Psychiatry 36, 1315-1321.

Beck Aaron, Rector Neil, Stolar Neal, Grant Paul. 2010. Schizofrenia w ujęciu poznawczym. Teoria, badania i terapia [Schizophrenia: Cognitive Theory, Research, and Therapy]. Kraków: Wydawnictwo Uniwersytetu Jagiellońskiego.

Bokus Barbara. 2005. "O przenikaniu się światów fabuły w narracji dziecięcej” [On the Crossing-over of Story Worlds in Children's Narration]. In: ChMielnicka-Kuter, PuCHALSKa-Wasyl 2005: 243-260.

Chmielnicka-Kuter Elżbieta, Puchalska-Wasyl Małgorzata. 2005. Polifonia osobowości. Aktualne problemy psychologii narracji [Polyphony of Personality. Current Issues in Psychology of Narration]. Lublin: Wydawnictwo KUL.

Covington Michael, He Congzhou Brown Cati, NaCi Lorina, McClain Jonathan, Fuordbak Bess, Semple James, Brown John. 2005. "Schizophrenia and the Structure of Language: the Linguist's View." Schizophrenia Research 77(1), 85-98.

Drat-RuszczaK Krystyna. 1995. Poznanie i emocje w schizofrenii. Różnicujący wplyw kontekstu społecznego [Cognition and Emotions in Schizophrenia. The Differentiating Influence of the Social Context]. Gdańsk: Wydawnictwo Uniwersytetu Gdańskiego.

DrYll Elżbieta, CierpKa Anna. 2011. Psychologia narracyjna. Tożsamość, dialogowość, pogranicza [Narrative Psychology. Identity, Dialogism, Borderlands]. Warszawa: Wydawnictwo Eneteia.

Dunau Bogusław. 2007. Wspótczesny stownik języka polskiego [Contemporary Dictionary of the Polish Language]. Warszawa: Wydawnictwo Langenscheidt Polska.

Janusz Bernadetta, Gdowska Katarzyna, De Barbaro Bogdan. 2008. Narracja. Teoria i praktyka [Narration. Theory and Practice]. Kraków: Wydawnictwo Uniwersytetu Jagiellońskiego.

JASTRZĘBSKA Julia, DryLl Elżbieta. 2008. “Autonarracja osób o różnych stylach przywiązania. Wybrane techniki formalnej analizy tekstu" [Autonarration of Persons with Different Attachment Styles. Selected Techniques of Formal Text Analysis]. In: JANusz et al. 2008: 133-153.

KaY Stanley, Fiszbein Abraham, Opler Lewis. 1987. "The Positive and Negative Syndrome Scale (PANSS) for Schizophrenia." Schizophrenia Bulletin 13, 2, 261-276.

KĘPIŃSKI Antoni. 2001. Schizofrenia [Schizophrenia]. Kraków: Wydawnictwo Literackie.

KUPERBERG Gina. 2010. "Language in Schizophrenia." Language and Linguistics Compass 4/8, 576-589.

Liemburg Edith, van der Meer Lisette, Swart Marte, Curcic-Blake Branislava, Bruggeman Richard, KnegTERING Henderikus, Aleman André. 2012. "Reduced Connectivity in the Self-processing Network of Schizophrenia Patients with Poor Insight." PloS ONE 7(8): e42707. doi: 10.1371/journal.pone.0042707.

McGlashan Thomas, Fenton Wayne. 1992. "The Positive-negative Distinction in Schizophrenia. Review of Natural History Validators." Archives of General Psychiatry 49, 63-73.

OBR̨̨вSKA Monika. 2011. "Analiza leksykalna tekstów wypowiedzi pacjentów ze zdiagnozowaną schizofrenią paranoidalną. Doniesienie z badań" [A Lexical Analysis of Utterance Texts of Patients Diagnosed with Paranoid Schizophrenia. A Research report]. In: OBRĘBSKA 2011a: 29-45.

OвręвSKA Monika. 2011a. O utrudnieniach w porozumiewaniu się. Perspektywa języka i komunikacji [On the Obstacles in Communicating. The Perspective of Language and Communication]. Poznań: Wydawnictwo Naukowe Wydziału Nauk Społecznych.

OBRĘBSKa Monika, NowaK Sandra. 2011. "The Level of Dogmatism in Schizophrenia. A Comparative Analysis of Utterance Texts with the Use of the Suitbert Ertel's Dogmatism Quotient." Psychology of Language and Communication 15(1), 49-62. 
OBRĘBSKA Monika, OBRĘBSKI Tomasz. 2011. "Style mówienia w schizofrenii. Analiza porównawcza z wykorzystaniem Wskaźników Stylów Mówienia Suitberta Ertela" [Styles of Speech in Schizophrenia. A Comparative Analysis Using Suitbert Ertel's Speech Styles Quotients]. Czasopismo Psychologiczne 17, 2, 161-170.

PALUChOWsKi Władysław Jacek. 2010. "Komputerowa analiza narracyjności. Wybrane problemy metodologiczne" [Computer Analysis of Narrativity. Selected Methodological Issues]. In: STRAś-RomanowsKa et al. 2010: 53-83.

Pennebaker James, Mehl Matthias, Niederhoffer Kate. 2003. "Psychological Aspects of Natural Language Use: Our Words, our Selves." Annual Review of Psychology 54, 547-577.

Pennebaker James, Stone Lori. 2003. "Words of Wisdom: Language Use Over the Life Span.” Journal of Personality and Social Psychology 85(2), 291-301.

Steuden Stanisława. 1997. Dynamika zmian osobowości u osób z rozpoznana schizofrenia. Badania dlugofalowe [Dynamics of Personality Change in Persons Diagnosed with Schizophrenia. Longitudinal Research]. Lublin: Wydawnictwo Katolickiego Uniwersytetu Lubelskiego.

Straś-Romanowska Maria, Bartosz Bogna, Żurko Magdalena. 2010. Badania narracyjne w psychologii [Narrative Research in Psychology]. Warszawa: Wydawnictwo Eneteia.

SzymczaK Mieczysław. 1982. Stownik języka polskiego [Dictionary of the Polish Language]. Warszawa: PWN.

TrZeBiŃski Jerzy. 2002. Narracja jako sposób rozumienia świata [Narration as a Way of Understanding the World]. Gdańsk: Gdańskie Wydawnictwo Psychologiczne.

Vetulani Zygmunt, WalczaK Bogdan, ObręBSKi Tomasz, Vetulani Grażyna. 1988. Jednoznaczne kodowanie fleksji rzeczownika polskiego i jego zastosowanie w stownikach elektronicznych - format POLEX [Unambiguous Coding of the Inflection of Polish Nouns and Its Application in Electronic Dictionaries - the POLEX Format]. Poznań: Wydawnictwo Naukowe UAM.

Watson Andrew, Defterali Cagla, Bak Thomas, Sorace Antonella, McIntosh Andrew, Owens David, JohnStone Eve, Lawrie Stephen. 2012. "Use of Second Person Pronouns and Schizophrenia." The British Journal of Psychiatry 200, 8, 342-343.

ŻuRKo Magdalena. 2008. "Wybrane metody analizy i interpretacji narracji autobiograficznej w ujęciu hermeneutycznym" [Selected Methods of Analysis and Interpretation of Autobiographical Narration According to the Hermeneutical Approach]. In: Janusz et al. 2008: 105-115. 